ISSN 0258-7122

Bangladesh J. Agril. Res. 39(1): 105-112, March 2014

\title{
PERFORMANCE OF SINGLE AND MIXED RHIZOBIAL INOCULANTS ON NODULATION, DRY MATTER AND SEED YIELD OF LENTIL (Lens culinaris)
}

\author{
M. A. H. BHUIYAN ${ }^{1}$, D. KHANAM ${ }^{2}$, M. T. RAHMAN ${ }^{3}$ \\ M. H. R. SHEIKH ${ }^{4}$ AND M. M. H. BHUIYAN ${ }^{5}$
}

\begin{abstract}
Field experiments were carried out at Regional Agricultural Research Station (RARS), Ishurdi, Pabna during the rabi season of 2005-06 and 2006-07 to find out the effectiveness of Rhizobium strains for achieving higher yield of lentil, the variety BARI Masur-4. There were six treatments that were Rhizobium strains- BARI RLc-104, BARI RLc-105, BARI RLc-106, BARI RLc-107, mixed culture of the four strains, and control (no Rhizobium). The experiment was designed in randomized complete block having 4 replications of each treatment.The rhizobial inocula were peat based and used @ $1.5 \mathrm{~kg} / \mathrm{ha}$. A basal dose of P@ 22 kg/ha, K @ 42 kg/ha, S @ 20 kg/ha, and @ 5 kg Zn/ha was used for all treatments. The highest nodule number (11.7/plant in 2006 and 10.3/plant in 2007) and dry nodule weight $(10.53 \mathrm{mg} / \mathrm{plant}$ in 2006 and $9.58 \mathrm{mg} / \mathrm{plant}$ in 2007) were found with mixed culture. Mixed culture produced the highest seed yield in 2006 (1.36 t/ha, 37.4\% higher over uninoculated control) and in 2007, BARI RLc-104 recorded the highest seed yield (1.23 t/ha, 60.3\% higher over uninoculated control). However, all the strains including mixed culture had similar seed yields over the years.
\end{abstract}

Keywords: Rhizobium, lentil, nodulation, yield.

\section{Introduction}

Lentil (Lens culinaris L.) occupies the top position in terms of popularity and has been placed second in respect of area and production in Bangladesh (BBS, 2011). It is cultivated during the rabi season under rainfed condition. About $86 \%$ of total lentil in the country is grown in Faridpur, Kushtia, Jessore, Rajshahi, and Pabna. The yield of lentil is very poor. In Bangladesh, pulses are grown in about $2,40,236$ ha and production is about 2,20,786 tons (BBS, 2011). Among the pulses, lentil is cultivated over an area of about 77,321 ha, production 71,100 tons, and mean production is about 0.920 tons/ha in Bangladesh (BBS, 2011). There is a great possibility to increase its production by exploiting better colonization of their root and rhizosphere through Rhizobium bacteria which can

\footnotetext{
${ }^{1}$ Principal Scientific Officer, Soil Science Division, Bangladesh Agricultural Research Institute (BARI), Gazipur-1701, ${ }^{2}$ Chief Scientific Officer (Ex.), BARI, Gazipur-1701, ${ }^{3}$ Senior Scientific Officer, Regional Agricultural Research Station RARS, Ishurdi, Pabna, ${ }^{4}$ Principal Scientific Officer, RARS, Ishurdi, Pabna, ${ }^{5}$ Scientific Officer, RARS, Hathazari, Chittagong, Bangladesh.
} 
reduce nitrogenous fertilizer use and protect environment. Bangladesh soils have lack of sufficient and effective Rhizobium strains in most of the cases (Khanam et al., 1999). Rahman et al. (2009) carried out field experiments to find out the effectiveness of BARI RLc-104, BARI RLc-105, BARI RLc-106, BARI RLc107 and mixed culture at southern part of Bangladesh in Agro-ecological Zone 13 (Ganges Tidal Floodplain) and found that mixed culture gave the highest nodulation and seed yield. While Bhuiyan et al. (1998c) observed that rhizobial inoculant, Mo and B together produced significantly higher nodule number, nodule and shoot weights, stover and grain yields over control at Old Himalayan Piedmont Plain (Agro-ecological Zone 01) of Bangladesh. Podder (1994) also found higher nodulation in lentil using different strains and mixed culture. $\mathrm{He}$ also reported that mixed culture gave higher total number of nodules, nodule dry weight, shoot dry weight, and N content than single strains L-101, L-107, and L120. Response of inoculation depends on soil type, cultivars, and effectiveness of Rhizobium strains and its competitive ability with native Rhizobium (Dube, 1976; Khanam et al., 1993). But, there is still lacking of sufficient, effective and resistant Rhizobium strains in soil. Moreover, degradation of Rhizobium occurs regularly. So, collection and screening of new Rhizobium strains and their subculturing and testing are necessary. For this reason, few indigenous Rhizobium strains were collected from different AEZs of Bangladesh and were screened. Now their efficiency in crop production needs to be tested. The present study was, therefore undertaken to find out the effectiveness of some Rhizobium strain/(s) on lentil at RARS, Ishurdi, Pabna of Bangladesh.

\section{Materials and Method}

Field experiments were carried out at Regional Agricultural Research Station (RARS), Bangladesh Agricultural Research Institute (BARI), Ishurdi, Pabna under Calcareous Dark Grey Floodplain Soils and in High Ganges River Floodplain (Agro-ecological Zone 11) during the rabi season of 2005-06 and 2006-07 to find out the effectiveness of Rhizobium strains on lentil. The initial soil sample of the experimental field was collected and analyzed following standard procedures in the laboratory and are presented in Table 1.

Table 1. Fertility status of the initial soil of the experimental field.

\begin{tabular}{|c|c|c|c|c|c|c|c|c|c|c|c|c|c|}
\hline \multirow[b]{2}{*}{ Station } & \multirow[b]{2}{*}{ H } & \multirow{2}{*}{$\begin{array}{c}\mathrm{OM} \\
\%\end{array}$} & $\mathrm{Ca}$ & $\mathrm{Mg}$ & $\mathrm{K}$ & \multirow{2}{*}{\begin{tabular}{|c} 
Total \\
$\mathrm{N}$ \\
$\%$
\end{tabular}} & $\mathrm{P}$ & $S$ & B & $\mathrm{Cu}$ & $\mathrm{Fe}$ & $\mathrm{Mn}$ & $\mathrm{Zn}$ \\
\hline & & & \multicolumn{3}{|c|}{$\mathrm{meq} / 100 \mathrm{~g}$} & & \multicolumn{7}{|c|}{$\mu \mathrm{g} \mathrm{g}^{-1}$} \\
\hline Ishurdi & 7 & 1.05 & 12.0 & 3.0 & 0.20 & 0.055 & 7.0 & 7.0 & .27 & 3.1 & 80 & 20.0 & 1.70 \\
\hline$C$ & 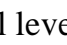 & & 2.0 & 0.5 & 0.12 & - & 10 & 10 & 0.20 & 0.20 & 4.0 & 1.0 & 0.60 \\
\hline
\end{tabular}

The soil was above neutral ( $\mathrm{pH} 7.50)$ having low organic matter (1.05\%). The content of total-N, available phosphorus, and available sulphur was very 
low. The exchangeable potassium was medium, available zinc was optimum, and available boron was low. The initial rhizobial population of the soil was below $10^{3}$. The experiment was laid out in randomized complete block design having four replications with six treatments. The unit plot size was $3 \mathrm{~m} \times 4 \mathrm{~m}$. The variety BARI Masur-4 of lentil and peat based rhizobial inocula BARI RLc-104, BARI RLc-105, BARI RLc-106, and BARI RLc-107 were used for the experiment. There were six treatments: $\mathrm{T}_{1}$ : Rhizobium strains BARI RLc-104, $\mathrm{T}_{2}$ : BARI RLc-105, $\mathrm{T}_{3}$ : BARI RLc-106, $\mathrm{T}_{4}$ : BARI RLc-107, $\mathrm{T}_{5}$ : mixed culture of the four strains under study and $\mathrm{T}_{6}$ : control (Without rhizobial inoculant). The studied peat based rhizobial inocula containing $10^{8}$ cells/g inoculum were used @ $1.5 \mathrm{~kg} / \mathrm{ha}$. Chemical fertilizers i.e., $\mathrm{P}, \mathrm{K}, \mathrm{S}$, and $\mathrm{Zn}$ were applied in all treatments as basal dose @ $22 \mathrm{~kg}$ P/ha from triple superphosphate, $42 \mathrm{~kg} \mathrm{~K} / \mathrm{ha}$ from muriate of potash, $20 \mathrm{~kg} \mathrm{~S} / \mathrm{ha}$ from gypsum and $5 \mathrm{~kg} \mathrm{Zn} / \mathrm{ha}$ from zinc oxide. The crop was sown on 23 November 2005 and 10 November 2006 with a spacing of $30 \mathrm{~cm} \mathrm{x}$ $10 \mathrm{~cm}$. During the course of the experiment, growth and development of plants in the field were carefully observed. Ten randomly selected plants along with roots were collected at 50\% flowering stage from each unit plot and dry weight of roots, shoots, and nodules including nodule numbers were recorded. The plants were harvested on 02 March 2006 and 28 February 2007. Data on plant height, 1000 -seed weight, stover yield, and seed yield were also taken plot-wise, pods/ plant and seeds/pod were taken from 10 randomly selected plants. Yield data were expressed on hectare basis. All data were analyzed statistically.

\section{Results and Discussion}

\section{Growth parameters}

Results on the effects of rhizobial inoculum on nodule number/plant, nodule weight (mg/plant), root weight ( $\mathrm{g} / \mathrm{plant}$ ), shoot weight ( $\mathrm{g} / \mathrm{plant})$, and plant height (cm) have been presented in Table 2. Results on pods/plant, seeds/pod, stover yield (t/ha), 1000-seed weight (g), and seed yield (t/ha) have been presented in Table 3. Inoculated plants produced significantly higher nodule number, nodule weight, root weight, and seed yield compared to uninoculated treatments in both the years. The effects of rhizobial inoculants on plant height and stover yield were found non-significant in 2006 and on shoot weight, stover yield, and 1000seed weight were non-significant in 2007. The effects of treaments on pods/plant and seeds/pod were non-significant in both the years.

Plants inoculated with mixed culture produced significantly higher number of nodules (11.72/plant in 2006 and 10.30/plant in 2007) over BARI RLc-104, BARI RLc-106 and uninoculated control, but identical to those recorded in BARI RLc-105 and BARI RLc-107 in 2006 and higher over BARI RLc-106 and uninoculated control but identical to BARI RLc-104, BARI RLc-105, and BARI RLc-107 in 2007 (Table 2). All inoculated plants produced statistically higher 
nodule number over uninoculated control. These results were supported by many other workers (Podder, 1994; Bhuiyan et al., 1998a; 1998b; 2000) that the Rhizobium was responsible for higher nodulation. Significant differences among strains in number of nodules/plant were also found for lentil (Bremer et al., 1990). Awan (1994) and Rahman et al. (2009) also reported that seed inoculation improved nodulation compared to that with the uninoculated control.

The highest nodule weight $(10.53 \mathrm{mg} / \mathrm{plant}$ in 2006 and $9.58 \mathrm{mg} / \mathrm{plant}$ in 2007) was observed in mixed culture, which was identical with all other strains both in 2006 and 2007 except BARI RLc-106 in 2007 (Table 2). All the strains recorded significantly higher nodule weight over uninoculated control in both the years. These results were similar to that of Bhuiyan et al. $(1998 \mathrm{~b} ; 2000)$ and Eusuf Zai et al. (2004). Such an increased nodule dry weights in lentil due to Rhizobium inoculation were also observed by other investigators (Yadav et al., 1992; Podder, 1994; Jain et al., 1995; Namdeo et al., 1996; Rahman et al., 2009).

Table 2. Effect of Rhizobium strains on nodulation, dry matter production and plant height yield of lentil.

\begin{tabular}{l|c|c|c|c|c}
\hline \multicolumn{1}{c|}{ Treatment } & $\begin{array}{c}\text { Nodule } \\
\text { no./plant }\end{array}$ & $\begin{array}{c}\text { Nodule wt } \\
(\text { mg/plant })\end{array}$ & $\begin{array}{c}\text { Root } \\
\text { wt } \\
(\mathrm{g} / \mathrm{plant})\end{array}$ & $\begin{array}{c}\text { Shoot } \\
\mathrm{wt} \\
(\mathrm{g} / \mathrm{plant})\end{array}$ & $\begin{array}{c}\text { Plant } \\
\text { height } \\
(\mathrm{cm})\end{array}$ \\
\hline 2006 & & & & \\
BARI RLc-104 & $10.29 \mathrm{~b}$ & $9.00 \mathrm{a}$ & $0.11 \mathrm{a}$ & $1.40 \mathrm{bc}$ & 34.8 \\
BARI RLc-105 & $10.01 \mathrm{ab}$ & $9.11 \mathrm{a}$ & $0.10 \mathrm{ab}$ & $1.66 \mathrm{a}$ & 34.9 \\
BARI RLc-106 & $9.27 \mathrm{~b}$ & $9.57 \mathrm{a}$ & $0.10 \mathrm{ab}$ & $1.73 \mathrm{a}$ & 35.1 \\
BARI RLc-107 & $11.51 \mathrm{ab}$ & $10.33 \mathrm{a}$ & $0.11 \mathrm{a}$ & $1.54 \mathrm{ab}$ & 35.8 \\
Mixed culture & $11.72 \mathrm{a}$ & $10.53 \mathrm{a}$ & $0.11 \mathrm{a}$ & $1.61 \mathrm{ab}$ & 35.3 \\
Control & $6.39 \mathrm{c}$ & $5.89 \mathrm{~b}$ & $0.09 \mathrm{~b}$ & $1.22 \mathrm{c}$ & 34.0 \\
\hline CV(\%) & 14.1 & 15.5 & 10.4 & 10.4 & 7.6 \\
\hline 2007 & & & & $38.6 \mathrm{ab}$ \\
BARI RLc-104 & $9.40 \mathrm{ab}$ & $8.90 \mathrm{ab}$ & $0.10 \mathrm{a}$ & 1.04 & $38.7 \mathrm{ab}$ \\
BARI RLc-105 & $9.20 \mathrm{ab}$ & $8.80 \mathrm{ab}$ & $0.09 \mathrm{ab}$ & 1.08 & $39.7 \mathrm{a}$ \\
BARI RLc-106 & $9.13 \mathrm{~b}$ & $8.53 \mathrm{~b}$ & $0.08 \mathrm{~b}$ & 1.10 & $37.6 \mathrm{ab}$ \\
BARI RLc-107 & $9.98 \mathrm{ab}$ & $9.20 \mathrm{ab}$ & $0.09 \mathrm{ab}$ & 1.15 & $35.4 \mathrm{~b}$ \\
Mixed culture & $10.30 \mathrm{a}$ & $9.58 \mathrm{a}$ & $0.10 \mathrm{a}$ & 1.18 & $35.4 \mathrm{~b}$ \\
Control & $6.13 \mathrm{c}$ & $5.40 \mathrm{c}$ & $0.08 \mathrm{~b}$ & 0.88 & 5.6 \\
\hline CV(\%) & 7.8 & 6.9 & 7.3 & 12.6 & \\
\hline
\end{tabular}

In a column, the figure(s) having same letter are not significantly different at $5 \%$ level by DMRT. 
Plants inoculated with mixed culture also gave the highest root weight $(0.11$ $\mathrm{g} / \mathrm{plant}$ in 2006 and $0.10 \mathrm{~g} / \mathrm{plant}$ in 2007) (Table 2). All the strains recorded statistically identical root weight. This was supported by many researchers (Dravid, 1991; Eusuf Zai et al., 2004). Strain BARI RLc-105 and BARI RLc-106 did not show significant effect on root weight over uninoculated control in 2006 and BARI RLc-105, BARI RLc-106, and BARI RLc-107 in 2007. Rhizobium strains had significant effect on shoot weight in 2006 only. Bhuiyan et al. (2000) observed that strains resulted higher shoot weight in groundnut. Rahman et al. (2009) also noted that rhizobial strains gave higher shoot weight in lentil. All the strains except mixed culture recorded identical response on plant height in 2007. This result was supported by Kumar and Agarwal (1993), Bhuiyan et al. (2000) and Rahman et al. (2009).

\section{Yield parameters}

Strains had no significant effect on pods/plant, seeds/pod and stover yields in both the years (Table 3). This result was supported by Kumar and Agarwal (1993) and Bhuiyan et al. (2000). Thousand seed weight did not show any definite trend, which was supported by Rahman et al. (2009).

Table 3. Effect of Rhizobium strains on yield and yield attributes of lentil.

\begin{tabular}{l|c|c|c|c|c}
\hline \multicolumn{1}{c|}{ Treatment } & $\begin{array}{c}\text { Pods/ } \\
\text { plant }\end{array}$ & $\begin{array}{c}\text { Seeds/ } \\
\text { pod }\end{array}$ & $\begin{array}{c}\text { Stover } \\
\text { yield } \\
(\mathrm{t} / \mathrm{ha})\end{array}$ & $\begin{array}{c}1000-\mathrm{seed} \\
\mathrm{wt} \\
(\mathrm{g})\end{array}$ & $\begin{array}{c}\text { Seed } \\
\text { yield } \\
\mathrm{t} / \mathrm{ha})\end{array}$ \\
\hline 2006 & & & & \\
BARI RLc-104 & 35.0 & 1.95 & 1.82 & $17.1 \mathrm{~b}$ & $1.33 \mathrm{a}$ \\
BARI RLc-105 & 34.2 & 1.92 & 1.99 & $17.9 \mathrm{a}$ & $1.21 \mathrm{a}$ \\
BARI RLc-106 & 34.1 & 1.90 & 1.95 & $17.9 \mathrm{a}$ & $1.29 \mathrm{a}$ \\
BARI RLc-107 & 33.2 & 1.94 & 1.86 & $17.3 \mathrm{~b}$ & $1.29 \mathrm{a}$ \\
Mixed culture & 35.3 & 1.97 & 1.97 & $18.0 \mathrm{a}$ & $1.36 \mathrm{a}$ \\
Control & 30.0 & 1.83 & 1.60 & $18.0 \mathrm{a}$ & $0.99 \mathrm{~b}$ \\
\hline CV(\%) & 10.1 & 7.6 & 11.4 & 2.1 & 9.2 \\
\hline 2007 & & & & & \\
BARI RLc-104 & 29.2 & 1.90 & 2.18 & 15.0 & $1.25 \mathrm{a}$ \\
BARI RLc-105 & 28.8 & 1.90 & 2.10 & 16.5 & $1.13 \mathrm{a}$ \\
BARI RLc-106 & 27.6 & 1.90 & 2.08 & 16.3 & $1.08 \mathrm{a}$ \\
BARI RLc-107 & 23.6 & 1.98 & 2.38 & 16.5 & $1.05 \mathrm{a}$ \\
Mixed culture & 25.2 & 1.93 & 2.35 & 15.7 & $1.18 \mathrm{a}$ \\
Control & 22.2 & 1.85 & 1.88 & 15.5 & $0.78 \mathrm{~b}$ \\
\hline CV(\%) & 17.0 & 6.2 & 12.8 & 7.7 & 15.7 \\
\hline
\end{tabular}

In a column, the figure(s) having same letter are not significantly different at $5 \%$ level by DMRT. 
Significant positive effect of Rhizobium inoculation on seed yield over uninoculated control was observed (Table 3). The mixture culture treatment recorded the highest seed yield of $1.36 \mathrm{t} / \mathrm{ha}$ (37.4\% higher over uninoculated control) and BARI RLc-104 recorded the highest seed yield (1.25 t/ha, 60.3\% higher over uninoculated control). All the strains gave statistically identical seed yield but different from uninoculated control. Higher nodulation, dry matter production, and seed yields might be due to the effect of Rhizobium inoculation on lentil. Bremer et al. (1990) reported that inoculation increased lentil yields by up to $135 \%$. Namdeo et al. (1996) also observed that inoculation increased seed yield by $17.5-23.2 \%$ compared to that with no inoculation. In the present study, inoculated lentil seeds with different strains increased seed yield by 22.2 to $60.3 \%$ compared to uninoculated control. The results were in agreement with the findings of Kumar and Agarwal (1993), Bhuiyan et al. (1998c), Khanam et al. (1996) and Khanam et al. (1999) who worked on lentil. Kantar et al. (1995) recorded significant increase in seed yield of lentil by applying Rhizobium strains.

Table 4. Effect of Rhizobium strains on $\mathrm{N}$ content in seed and stover, and $\mathrm{N}$ uptake by seed and stover of lentil.

\begin{tabular}{|c|c|c|c|c|}
\hline \multirow{2}{*}{ Treatment } & \multicolumn{2}{|c|}{$\mathrm{N}$ content $(\%)$} & \multicolumn{2}{|c|}{$\mathrm{N}$ uptake $(\mathrm{kg} / \mathrm{ha})$} \\
\hline & Seed & Stover & Seed & Stover \\
\hline \multicolumn{5}{|l|}{2006} \\
\hline BARI RLc-104 & $3.50 \mathrm{a}$ & $1.57 \mathrm{a}$ & $46.38 \mathrm{a}$ & 28.57 \\
\hline BARI RLc-105 & $3.40 \mathrm{e}$ & $1.54 \mathrm{c}$ & $41.04 \mathrm{a}$ & 30.60 \\
\hline BARI RLc-106 & $3.44 \mathrm{~d}$ & $1.54 \mathrm{c}$ & $44.29 \mathrm{a}$ & 30.02 \\
\hline BARI RLc-107 & $3.45 \mathrm{c}$ & $1.53 \mathrm{~d}$ & $44.42 \mathrm{a}$ & 28.42 \\
\hline Mixed culture & $3.46 \mathrm{~b}$ & $1.56 \mathrm{~b}$ & $47.15 \mathrm{a}$ & 30.72 \\
\hline Control & $3.22 \mathrm{f}$ & $1.47 \mathrm{e}$ & $31.82 \mathrm{~b}$ & 23.45 \\
\hline $\mathrm{CV}(\%)$ & 5.6 & 1.3 & 9.2 & 11.2 \\
\hline \multicolumn{5}{|l|}{2007} \\
\hline BARI RLc-104 & $3.41 \mathrm{a}$ & $1.53 \mathrm{a}$ & $42.63 a$ & 33.28 \\
\hline BARI RLc-105 & $3.33 b$ & $1.51 \mathrm{~b}$ & $37.49 \mathrm{a}$ & 31.72 \\
\hline BARI RLc-106 & $3.34 \mathrm{~b}$ & $1.50 \mathrm{c}$ & $35.90 \mathrm{a}$ & 31.08 \\
\hline BARI RLc-107 & $3.34 \mathrm{~b}$ & $1.49 \mathrm{~d}$ & $35.04 \mathrm{a}$ & 35.41 \\
\hline Mixed culture & $3.38 \mathrm{ab}$ & $1.53 \mathrm{a}$ & $39.68 \mathrm{a}$ & 35.95 \\
\hline Control & $3.21 \mathrm{c}$ & $1.45 \mathrm{e}$ & $24.88 \mathrm{~b}$ & 27.20 \\
\hline$\overline{\mathrm{CV}(\%)}$ & 5.7 & 1.2 & 15.6 & 12.6 \\
\hline
\end{tabular}

In a column, the figure(s) having same letter are not significantly different at $5 \%$ level by DMRT. 


\section{$N$ content and $N$ uptake}

Plants inoculated with strain BARI RLc-104 gave the highest N content in seed and stover in both the years (Table 4). The highest $\mathrm{N}$ content in seed recorded by BARI RLc-104 was significantly different from all other strains including mixed culture and control in 2006, but it was identical with that recorded in only mixed culture in 2007, and the highest $\mathrm{N}$ content in stover was found in BARI RLc-104, which was statistically different from all other strains. Uninoculated control gave the lowest $\mathrm{N}$ content in seed and stover.

Plants inoculated with mixed culture gave the highest $\mathrm{N}$ uptake by seed in 2006, which was identical with all other strains but in 2007, the highest $\mathrm{N}$ uptake by seed was observed by strain BARI RLc-104, which was also identical with those recorded all other strains (Table 4). Plants without inoculum produced the lowest $\mathrm{N}$ uptake by seed, which was inferior to all the strains. Strains had no significant effect on $\mathrm{N}$ uptake by stover though the highest value was noted in mixed culture and the lowest in uninoculated control.

\section{Conclusion}

Mixed culture of lentil rhizobia showed better performance in nodulation. Seed yields were statistically non-significant between single and mixed culture treatments. Nitrogen content and uptake were higher in inoculated plants. Due to lower native rhizobial numbers and soil $\mathrm{N}$ characters, mixed culture inoculation approach might have a positive effect on lentil cultivation in Calcareous Dark Grey Floodplain Soil of Bangladesh. From two years' results, it could be recommended that mixed culture of different Rhizobium strains or BARI RLc-104 was suitable for obtaining higher seed yield of lentil at western region of Bangladesh.

\section{References}

Awan, M. F. M. 1994. Ontogenetic variation of nodulation, nitrogen fixation and nitrogen accumulation in lentil (Lens culinaris Medic) I. Soil characteristics, nodulation and plant yield. Acta Physiologiae Plantarum 16(3): 163-169.

Bangladesh Bureau of Statistics. 2011. Yearbook of Agricultural Statistics of Bangladesh. Bangladesh Bureau of Statistics. Ministry of Planning, Govt. People's Republic of Bangladesh, Dhaka. Pp. 108-109.

Bhuiyan, M. A. H., M. S. Kabir and D. Khanam. 1998c. Effects of boron, molybdenum and rhizobial inoculation on nodulation and yield of lentil. Bangladesh J. Seed Sci. Tech. 21(1\&2): 39-44.

Bhuiyan, M. A. H., D. Khanam, M. M. Rahman and M. M. Ali. 1998a. Variation in the symbiotic effectiveness of Bradyrhizobium strains on soybean. Bangladesh $J$. Microbiol. 15(1): 25-30.

Bhuiyan, M. A. H., M. M. Rahman, D. Khanam and N. C. Basak. 2000. Effects of different Bradyrhizobium strains on nodulation, dry matter production and yield of groundnut. Bangladesh J. Microbiol. 17(1): 41-44. 
Bhuiyan, M. A. H., M. M. Rahman, D. Khanam and M. A. Khaleque. 1998b. Nodulation and yield of groundnut in relation to strains of Bradyrhizobium. Bangladesh J. Sci. Ind. Res. 33(3): 323-326.

Bremer, E., C. Kessel, L. Nelson, R. J. Rennie, D. A. Rennie and C. Van-Kessel. 1990. Selection of Rhizobium leguminosarum strains for lentil (Lens culinaris) under growth room and field conditions. Plant Soil. 121(1): 47-56.

Dravid, M. S. 1991. Effect of salinization, Rhizobium inoculation, genotypic variation and P-application on dry matter yield and utilization of P by pea (Pisum sativum L.) and lentil (Lens culinaris Medic). J. Nuclear Agric. Biol. 19(4): 227-231.

Dube, N. N. 1976. Yield response of soybean, chickpea and lentil to inoculation with legume inoculants. In: Symbiotic Nitrogen Fixation in Plants. Nutman, P. S., ed. Cambridge University Press, Cambridge. Pp. 385-403.

Eusuf Zai, A. K., D. Khanam, M. H. Ullah, M. A. H. Bhuiyan and A. K. M. Quamruzzaman. 2004. Effect of Rhizobium inoculation on gardenpea (Pisum sativum) in Noncalcareous Grey Floodplain Soil of Bangladesh. Thai J. Agric. Sci. 37(4): 299-304.

Jain, R. C., R. J. Tiwari and D. P. Nema. 1995. Integrated nutrient management for lentil under rainfed conditions in Madhya Pradesh. II. Nodulation, nutrient content and economics. LENS Newsletter 22(1\&2): 13-15.

Kantar, F., T. Kiziloglu, O. Caglar and S. Akien. 1995. Lentil yield in relation to Rhizobium leguminosarum inoculation in eastern Anatolia. LENS Newsletter 21(2): 36-40.

Khanam, D., M. A. H. Bhuiyan, M. H. H. Rahman and A. K. M. Hossain. 1999. On-farm experience of the application and adoption of biological nitrogen fixation technology in Bangladesh. Bangladesh J. Agril. Res. 24(2): 375-382.

Khanam, D., M. H. H. Rahman, M. A. H. Bhuiyan, A. K. M. Hossain and A. F. M. Rahman. 1993. Effect of rhizobial inoculation and chemical fertilizers on the growth and yield of lentil at two Agro-ecological Zones of Bangladesh. Bangladesh J. Agril. Res. 18(2): 196-200.

Khanam, D., M. H. H. Rahman, M. A. H. Bhuiyan, M. Z. Islam, A. F. M. Rahman and A. K. M. Hossain. 1996. Varietal screening of lentil (Lens culinaris L.) in presence and absence of Rhizobium inoculation. Progress. Agric. 7(2): 143-146.

Kumar, P. and J. P Agarwal. 1993. Response of lentil to Rhizobium inoculation, nitrogen and phosphorus fertilization. Indian J. Agron. 38(2): 318-320.

Namdeo, S. L., S. C. Gupta and R. K. Joshi. 1996. Influence of rhizobial inoculation on nodulation and yield of lentil genotypes under rainfed conditions. LENS Newsletter 23(1\& 2): 24-26.

Podder, A. K. 1994. Performance of single and mixed rhizobial inocula for nodulation and growth of lentil. LENS Newsletter 21(1): 39-40.

Rahman, A. K. M. H., M. A. H. Bhuiyan, D. Khanam, M. E. Ali and F. Alam. 2009. Effect of Rhizobium strains on nodulation, dry matter production and yield of lentil. Bangladesh J. Agriculturists 2(2): 133-136.

Yadav, K., V. Prasad, K. Mandal and N. Ahmad. 1992. Effect of co-inoculation (Azospirillum and Rhizobium) on nodulation, yield nutrient uptake and quality of lentil in calcareous soil. LENS Newsletter 19(2): 29-31. 